\title{
FATHOM
}

\section{The Abyss, the Image and the Turn: Writing Desire in Three Poems by Thomas Hardy}

L'abysse, l'image et le retournement: l'écriture du désir dans trois poèmes de Thomas Hardy

Jane Thomas

\section{OpenEdition}

\section{Journals}

Electronic version

URL: http://journals.openedition.org/fathom/855

DOI: $10.4000 /$ fathom.855

ISSN: 2270-6798

\section{Publisher}

Association française sur les études sur Thomas Hardy

Electronic reference

Jane Thomas, "The Abyss, the Image and the Turn: Writing Desire in Three Poems by Thomas Hardy », FATHOM [Online], 5 | 2018, Online since 22 April 2018, connection on 03 May 2019. URL : http:// journals.openedition.org/fathom/855 ; DOI : 10.4000/fathom.855

This text was automatically generated on 3 May 2019. 


\title{
The Abyss, the Image and the Turn: Writing Desire in Three Poems by Thomas Hardy
}

\author{
L'abysse, l'image et le retournement : l'écriture du désir dans trois poèmes de \\ Thomas Hardy
}

Jane Thomas

1 This essay centres on three themes: the relationship between the desiring subject, the power of the gaze and the writing process. Here I revisit the final chapter of my book Thomas Hardy and Desire: Conceptions of the Self (2013) and acknowledge a debt to Annie Ramel's most recent study of Hardy: The Madder Stain: A Psychoanalytic Reading of Thomas Hardy.

2 I understand "desire" as "the energy of the human spirit as it struggles for articulation and recognition against, on the one hand, the impossible and unspeakable nature of the Real and, on the other, the productive constraints of language" (Thomas 2). The "gaze" I define here as the "Orphic turn" away from its object: not exactly the "look awry" (askew or to one side) but the deliberate turn away from the object of desire in order to draw or lead it out of the realm of the unspeakable and into the compromised arena of language. My "desiring subject" is Orpheus: the spirit of the artist writer, embodied in the texts of Hardy's elegiac (and other) poems, in the form of their various first-person narrative "voices": what we might call (in a nod to J. B. Bullen) the "Expressive I" (Bullen 1986). I take as my test cases three poems by Hardy: "Where the Picnic Was", "The Voice" and "The Shadow on the Stone".

3 In "The Freudian Unconscious and Ours" 1 Lacan focusses on the "stumbling", the "impediment", the "failure" in language in which he locates the "discovery" or "surprise" wherein the poet seeks to push beyond the apparent limits of language in order to grasp at, and perfect, a fleeting moment of plenitude. For Lacan, desire inheres in the gap between signifier and signified - it is what cannot be represented in language and yet strives for material form in the only medium available to it. The urge to move beyond the 
constraints of language into the pre- or "post" linguistic realm carries with it the threat of incoherence, dissolution, silence. In a formal sense, and on the page, such stumblings reveal themselves in Hardy's poetry in the broken line, the ellipsis, the ejaculation, and the image or symbol which adds further resonance to the sign - which is itself a substitute for the absent "thing". For Lacan:

$\mathrm{Th}[\mathrm{e}]$ discovery is, at the same time, a solution - not necessarily a complete one, but, however incomplete it may be, it has that indefinable something that touches us, that peculiar accent...surprise, that by which the subject feels himself [sic] overcome, by which "he" finds both more and less than he expected but in any case, it is, in relation to what he expected, of exceptional value (Lacan 25).

The "discovery" is the solution, and by "solution" we may understand that which resolves and settles as well as that which dissolves and disperses: the solvent which breaks up the arrogance of the sign. The image or symbol strives to substantiate the fugitive moment in language and yet "as soon as it is presented it becomes a rediscovery and, furthermore, it is always ready to steal away again, thus establishing the dimension of loss" (Lacan 25). As soon as we turn to grasp our desire it vanishes back into the Abyss of the Real. The image or symbol stands between the sign and the abyss of the Real. Lacan acknowledged the role of the artist - and particularly the poet - in the struggle to wrestle language into meaning and how the urge to get behind, beyond or inside the sign in order to exploit its potential to the full in the work of art carries with it the risk of incoherence, failure and dissolution.

Hardy copied a passage from John Addington Symonds' essay on Pater's "The School of Giorgione" in Essays Speculative and Suggestive - including Symonds' thoughts on the role of symbols in Art (Symonds 188-189). Symonds declares that it is "the business of Art to use [...] symbols in a double way. They must be used for the direct representation of thought and feeling; but they must also be combined by so subtle an imagination as to suggest much which is there is no means of directly expressing" (Hardy 1985 II, 43, n1865). For Pater the symbol constitutes "the expiration" of the sign's "definite meaning". The poetic symbol reaches beyond its manifest meaning as a sign to bring that which is beyond or surplus into the realm of consciousness.

In his elegiac poems of 1912-13 Hardy's bereaved narrators are situated - Orpheus-like on the boundary between life and death, between the attainment of the lost object of desire and the annihilation of self, on the very edge of the unspeakable abyss where the subject dissolves. Some of Hardy's best elegies imagine, describe and embody this dilemma: the narrator's agonized attempt in "The Voice" (Hardy 1984, 56-57) to hear and read the thin oozing of the wind through the thorn tree as the voice of the dead beloved, who calls him to join her in the "air-blue" realm of death; the ungendered narrator of "Under the Waterfall" (45-46) reliving the imagined retrieval of a long-lost picnic glass in the physical sensation of washing in a bowl of cold water, the narrator of "Where the Picnic Was" (69-70) gazing into the "abyss" of the burnt circle for one who has "shut her eyes for evermore", or the mourner of "The Shadow on the Stone" who is tempted to try and bring the dead woman out of the abyss but who, in the end, refuses to turn and "unvision" her. Through such potent, suggestive and articulate symbols as the wind, the "chalice" of "Under the Waterfall", the burnt circle and the shadow, Hardy raises the sign to what Symonds describes as "a higher power" wherein each "continues to be an articulate sound \& a logical step in the argument; but it becomes also a musical sound \& a centre of emotional force" (Hardy 1985 II, 43, n1865). 
7 For Annie Ramel, the "absolute negativity" of the Real equates to Virginia Woolf's idea of the "centre of complete emptiness" which is a prerequisite for any creation, which is always a creation ex nihilo (out of nothing): like Heidegger's vase "all art is characterised by a certain mode of organisation around this emptiness" (Ramel 159). The burnt circle and the imagined chalice shape themselves around empty or blank space while the wind and the shadow, in their visual and haptic intangibility, embody precisely what cannot be apprehended or grasped. Each modifies or offers a semi-permeable barrier which allows us, in Ramel's words, "to approach the very limit beyond which lies the impossible Thing without being blinded by its absolute negativity" (124). What is also retrieved is a retrospectively imagined time of plenitude: "that day" when the now dissolved "band" came to picnic on the spot, "the fugitive day" of the lover's picnic by the waterfall; the "day" ("our day") that "was fair" in "The Voice" and in "The Shadow on the Stone", the gardening days of the now dead woman. Each "fugitive day" is "Fetched back from its thickening shroud of gray" to be relived again and again by narrator, poet and reader.

"Where the Picnic Was" was originally published in 1914 and added to the "Poems of 1912-13" in 1919 thus constituting, as Tim Armstrong declares, "the last poem of the sequence in its extended final version" (Hardy 2009, 173). The narrator climbs a hill to the sea, "Through winter mire", to revisit the site of a picnic which took place in the previous summer. His gaze, and the translation of its object - the dark circle - into text, is suggested by the verbs "scan" and "trace", and the "charred stick ends" that "still strew the sward" can be read as symbols of the writing instrument - the charcoal that shapes living words out of carbon (the key component of life) and ash. A "burnt circle" marks the spot of lost plenitude and, as Armstrong suggests, the traces of the picnic fire link to the epigraph from Virgil's Aeneid that Hardy appended to the sequence: "Veteris vestigia flammae" ("ashes" or "traces" of the old fire). The words are spoken by Dido to describe the rekindling, by Aeneas, of feelings of love which died with her husband Sychaeus. On one level the reference suggests the rekindling of desire in its original site ("Where we made the fire"). However, in Virgil's Aeneid the abandoned Dido immolates herself on a funeral pyre as she watches Aeneas's ships sail away. In Hardy's poem, the burnt circle and the charred sticks divert the narrator's gaze from the dark abjection of death while simultaneously offering the means of expression to the "I" that seeks to gaze past and through it to oblivion. The "vestigia" or "vestigio" can be translated as the" vestige" or faint mark or visible sign left by something which is lost: the "burnt circle" is the visible sign of the lost object of desire made manifest in the visible sign of the symbol - the black nothing - around which the poem organises itself. The boundary between the narrator and the abyss of the dark circle, and what it symbolises, is literally figured in the poem by a sequence of three dashes. The first occurs in line four of the second stanza and physically separates the "burnt circle" and the word "aye", which functions here as an affirmation of the discovery and presence of the physical "spot" - one which perhaps the narrator feared might have greened over in the intervening time. The second dash occurs in the final stanza, separating the "band" containing the narrator from the moment of the band's imminent dissolution: the removal of two of its members to "the urban roar / Where no picnics are". This leaves our narrator still companioned by the third member of the "band". The necessary separation of the narrator from the "one" who "has shut her eyes /For evermore" in death is accomplished by the third dash in the final line which takes "him" to the very brink of the abyss whilst holding "him" in the "here". It is as if the narrator, like Conrad's Marlow in Heart of Darkness, peers into the pit of abjection into 
which Kurtz has descended but remains balanced on its edge. If we read the narrator's ejaculation on discovering the burnt circle as "Aye": the archaic word for "forever", we recognise an echo of the final word of the poem "'evermore" suggesting how the fugitive moment that both caused, and is embodied in, the "burnt circle" is given permanence by the words themselves and the symbolic function they perform.

Hardy's "The Voice" likewise movingly enacts the way in which the symbolic forms what Ramel calls "a rim around the void of the Real" (Ramel 20). The process is worked through in this sublime (sub-limen) poem in the narrator's agonised attempt to translate the sound of the "wind oozing thin through the thorn" into the recognisable voice of the dead woman and to bring her, in person, out of the realm of memory and into the material world. The unbearable object which the narrator seeks access to is the objectgaze in "his" request to "view you then". It is also the object sound - the sound of the silence of "non-being" or extinction symbolised by the intangible breath of the wind that is caught, concentrated and "riddled" by the net of the thorn tree.

As in "Where the Picnic Was", the narrator negotiates the barrier between the abyss of death and the faltering ground of life in the poem's stumbling punctuation and metre. The barrier or rim is figured twice in the second stanza in the form of the interrogation mark in the first line "Can it be you that I hear? Let me view you then", and the colon in the third line "Where you would wait for me: yes, as I knew you then". Here the narrator seeks access to the imagined realm of the past - willing the dead woman to facilitate "his" passage. The dangerous translation from life to death, from presence to "air-blue" dissolution, is given momentum by the dactylic metre that runs almost unbroken throughout the stanza, and the run-on second and third line that almost propels us across the strong caesura of the colon. The resolution is reached in the powerful final stanza and figured in the semi-colon between "Thus I" and "faltering forward".

11 The narrator's reluctant movement away from the other side is suggested by the broken, stumbling shift in the rhythm as the dactylic / trochaic metre of the first three stanzas falters to spondees before briefly regaining momentum in the penultimate line in the turn away from the "calling woman", whose echo is nevertheless immortalised in the reversed iambs of the final line. Now a separation is enacted between the voice of the woman and the sound of the wind which is onomatopoeically rendered in the sublime line: "Wind oozing thin through the thorn from norward". To read the line aloud is to form the lips as if to blow or to kiss, as if the dead woman herself acknowledges the narrator's necessary retreat. As the narrator moves, albeit reluctantly, away from the rim, turning his back on the net of sound that threatened to catch him in its interstices, he carries the image of the calling woman into the realm of the symbolic where it echoes evermore in the final lines of the final stanza. The question "Can it be you that I hear?" remains unanswered - necessarily so perhaps, for if the breath of the wind had actually shaped itself to the voice of the dead woman, if the summons to her to show herself "'Yes, as I knew you then" were obeyed, the narrator would be drawn into the abyss of nonbeing-dissolved (like the wind and the lost beloved) "to wan wistlessness / Heard no more again far or near". If we accept that the breath of the wind - intangible, invisible until modified by objects - fails to shape itself into the voice of the dead beloved, then whose is "The Voice" of the poem's title? Are we "listening" to and imagining, in that sublime penultimate line, the voice of the dead woman calling or the voice of the poet giving substance to that of the narrator who has "his" being only in and as the text of the poem? 
The Orphic "turn" features quite literally once again as the turning point of "The Shadow on the Stone". This has been recognised and usefully commented upon by Melissa Ziegler who notes the role of the "phantom woman" as a muse for the male elegist who is eventually led "to exchange the dead female body for poetic empowerment" (Ziegler 45). Whilst acknowledging Hardy's revisionary contribution to the elegiac tradition, she questions his yearning nostalgia and persistent recalling of "Emma" "often literally as a ghost", as "somewhat paradoxical in light of [his] notorious estrangement" from his wife in real life (45). Zeigler's reservations typify the constraints of the biographical reading of these superb poems. Can the life be used as a measure of the success of the art? How can we accept the idea of the violence done to the body / phantom of Emma by her elegist husband unless we constrain the art in the straitjacket of biography and the assumption of gender? The "I" and "You" of "Shadow on the Stone" exist only as text, as marks on a page that nonetheless figure loss. In Symonds' words they "introduce an equivalent for what [they] cannot represent" (Hardy 1985 II, 36, n1833). While the "you" is clearly gendered as female, no such assumption can be made concerning the gender of the narrator - the expressive "I". Are we as readers confined to an appreciation of the poem that has resonance for us only if we imagine ourselves as Thomas Hardy and Emma? Clearly not. The affective power of the "Poems of 1912-13" goes far beyond the fraught relationship between the poet and his wife, even though her sudden death was indisputably the catalyst for these elegies. Maintaining the undecidability of gender - in so far as the poems allow (and so many of them do just this) - opens them out to any reader in all the richness and resonance of their evocation of loss. Indeed, the poems take on new significances if we gender the narrators of poems such as "The Voice" or "The Shadow on the Stone" against the biographical bias, as bereaved daughters, mothers, grandmothers, sisters, civil partners. In the process of mourning, in the "turning back" to, or the "turning away" of the bereaved from the lost beloved, and the lonely faltering forward, all mourners are Orpheus. The addendum of "The Shadow on the Stone" offers the information: "Begun 1913: finished 1916", demonstrating how the raw material of personal loss is refined in the crucible of art - just as the lost picnic glass of "Under the Waterfall" is opalised by the gentle scouring of water and time.

Zeigler reads "The Shadow on the Stone" as evidence of the fatal turn of Orpheus to gaze at the dead Eurydice thereby condemning her to Hades forever. However, unlike Orpheus who turns to reassure himself that his wife is indeed behind him, our narrator resists the impulse. In his imagination the shadows on the stone shape themselves to "the shade that a well-known head and shoulders / Threw there" - a shape which fails to materialise as the dead woman herself, just as the inarticulate "voice" of the wind through the thorn fails to become that of the "woman much missed". Like the burnt circle and the thorn, the shadow mediates between the narrator and the object of his desire translating it from a yawning "nothing" to a compromised yet comforting presence. Like Orpheus the narrator has to trust that Eurydice is indeed behind him. To glance back would be to destroy the conceit to "unvision" both the "Expressive I" and "Expressed You". We snag on that typically Hardyian neologism "unvision': the verbification of "vision" suggesting the gaze, the act of gazing and the object of the gaze while the negation suggests to disabuse or undeceive - even blind. And to whom does it apply? The would-be gazer or the "shape" that throws her shade against the Druid stone?

14 The shadow on the stone can be read here as the object that provides a correlative for the absolute negativity of death: the object that modifies the unbearable emptiness of the 
abyss that the narrator eventually turns away from. The "shade" of "the well-known head and shoulders" - with its connotations of ghost and shadow - figures, in its partialness, the absolute darkness of the realm beyond or before representation, forming the edge or border between reality and the Real. Contrary to what Zeigler assumes, here the orphic narrator does not turn around to confront the dead beloved. It follows then that instead of losing her forever, and losing him/herself in the abject certainty of that loss, she is preserved in the image of the shadow on the stone - a metaphor for the shadow of the sign, the word, the symbol and the material record of the sublime elegy.

\section{BIBLIOGRAPHY}

Bullen, J. B., The Expressive Eye: Fiction and Perception in the Work of Thomas Hardy, Oxford: OUP, 1986.

Hardy, Thomas, Selected Poems, ed. Tim Armstrong, Harlow: Pearson, 2009.

Hardy, Thomas, The Complete Poetical Works of Thomas Hardy, ed. Samuel Hynes, Vol. 2, 1984.

Hardy, Thomas, The Literary Notes of Thomas Hardy, ed. Lennart Björk, 2 vols., Basingstoke: Macmillan, 1985.

Lacan, Jacques, The Four Fundamental Concepts of Psycho-Analysis, ed. J.-A. Miller, trans. Alan Sheridan, London: The Hogarth Press and the Institute of Psychoanalysis, 1977.

Ramel, Annie, The Madder Stain, A Psychoanalytic Reading of Thomas Hardy, Leiden: Brill-Rodopi, 2015.

Symonds, John Addington, Essays Speculative and Suggestive, London: Chapman Hall, 1890.

Thomas, Jane, Thomas Hardy and Desire, Conceptions of the Self, Basingstoke: Palgrave Macmillan, 2013.

Ziegler, Melissa, Beyond Consolation: Death, Sexuality, and the Changing Shape of Elegy, New York and London: Ithaca, Cornell UP, 1997.

\section{NOTES}

1. Chapter 2 in The Four Fundamental Concepts of Psychoanalysis. 


\section{ABSTRACTS}

This essay examines the relationship between the desiring subject, the power of the gaze and the writing process. "Desire" is understood as "the energy of the human spirit as it struggles for articulation and recognition against, on the one hand, the impossible and unspeakable nature of the Real and, on the other, the productive constraints of language" (Thomas 2). The "gaze" is defined here as the "Orphic turn" away from its object: not exactly the "look awry" (askew or to one side) but the deliberate turn away from the object of desire in order to draw or lead it out of the realm of the unspeakable and into the compromised arena of language. The "desiring subject" is Orpheus, the spirit of the artist writer, embodied in the texts of Hardy's elegiac poems, in the form of their various first-person narrative "voices": what might be called (in a nod to J. B. Bullen) the "Expressive I". The essay takes as test cases three poems by Hardy: "Where the Picnic Was"; "The Voice" and "The Shadow on the Stone".

Cet article se propose d'étudier la relation entre le sujet désirant, le pouvoir du regard et le procédé d'écriture. Le « désir » s'entend ici au sens de « l'énergie de l'esprit humain dans sa lutte pour l'expression et la reconnaissance face, d'une part, à l'impossible et indicible nature du Réel et, d'autre part, aux contraintes productives du langage » (Thomas 2). Le « regard » est quant à lui défini comme le «retournement orphique» qui l'éloigne de son objet: il ne s'agit pas véritablement d'un « regard détourné » (de travers ou de côté) mais plutôt d'un détour délibéré qui éloigne de l'objet du désir afin de l'extraire du domaine de l'indicible pour le faire entrer dans l'espace compromis du langage. Le "sujet désirant " est Orphée, esprit de l'écrivain artiste présent dans le texte des poèmes élégiaques de Hardy sous la forme des diverses "voix » narratives de la première personne : ce que l'on pourrait nommer (en référence à J. B. Bullen) "the Expressive I ». Trois poèmes de Hardy viennent illustrer cette étude: "Where the Picnic Was", "The Voice" et "The Shadow on the Stone".

\section{INDEX}

Mots-clés: désir, regard, écriture, sujet, voix, élégie, retournement, Orphée

Keywords: desire, gaze, writing, subject, voice, elegy, turn, Orpheus

oeuvrecitee Where the Picnic Was, Voice (The), Shadow on the Stone (The)

\section{AUTHOR}

\section{JANE THOMAS}

Professor Thomas is an internationally-recognised expert and author of several book and articles on the life and work of Thomas Hardy. Her media appearances include Radio 4's In Our Time and Woman's Hour, BBC 2's Great British Railway Journeys and BBC 4's Books that Made Britain. Professor Thomas also publishes on Victorian sculpture and visual arts, modern and contemporary women's writing, and literature and place. Her research has been funded by the British Academy 
and the AHRC, she was appointed Research Fellow of the Henry Moore Institute in 2013 and she has been Academic Director of the International Thomas Hardy Conference since 2010.

Source: http://www.hull.ac.uk/faculties/staff-profiles/jane-thomas.aspx 